\title{
Taxonomy of xanthomonads from cereals and grasses based on SDS-PAGE of proteins, fatty acid analysis and DNA hybridization
}

\author{
L. Vauterin, ${ }^{*}$ P. Yang, B. Hoste, B. Pot, J. Swings and K. Kersters \\ Laboratorium voor Microbiologie, Ledeganckstraat 35, Universiteit Gent, 9000 Gent, Belgium
}

(Received 2 December 1991; revised 10 March 1992; accepted 3 April 1992)

\begin{abstract}
Strains of all Xanthomonas species, $X$. campestris pathovars pathogenic for cereals and grasses and strains of $X$. campestris pv. campestris were compared by SDS-PAGE of proteins, gas chromatography of fatty acid methyl esters and DNA-DNA hybridization. The groupings derived using all three methods correlated well with each other. Strains of $X$. axonopodis and $X$. campestris pv. vasculorum were heterogeneous, each comprising two groups (A and B); group A contained the type strain and pathovar reference strain, respectively. Besides the recognized Xanthomonas species $X$. albilineans, $X$. campestris, $X$. fragariae, $X$. maltophilia, $X$. oryzae and $X$. populi, the following five centres of variation could be delineated at DNA-binding levels of above $60 \%$ : (i) a group consisting of $X$. campestris pathovars translucens, hordei, cerealis, secalis, undulosa (the 'translucens group'), graminis, poae, arrhenatheri, phlei (the 'graminis group') and phleipratensis; (ii) $X$. axonopodis type A together with $X$. campestris pv. vasculorum type $A$ and $X$. campestris pv. coracanae; (iii) a group of $X$. campestris pv. vasculorum type B and $X$. campestris pv. holcicola; (iv) Xanthomonas strains isolated from Bromus; and (v) strains isolated from sugarcane in Guadeloupe. The type B strains of $X$. axonopodis appeared to be misclassified in Xanthomonas. An interim proposal for an improved classification of Xanthomonas is presented on the basis of the data.
\end{abstract}

\section{Introduction}

Many plant pathogens which were originally designated as separate Xanthomonas species were grouped into the single species $X$. campestris by Dye \& Lelliott (1974) on the basis of their phenotypic uniformity. A specialpurpose classification, distinguishing the former species as pathovars of $X$. campestris, was subsequently established (Dye et al., 1980; Young et al., 1978). However, with the development of taxonomic techniques such as electrophoresis of proteins and gas chromatography of fatty acids combined with computer-aided analysis of profiles, it became apparent that a number of phenotypes could be distinguished among strains called $X$. campestris (Stead, 1989; Vauterin et al., 1990a 1991 a). A number of the phenotypically distinct $X$. campestris groups were found to correspond to groups revealed by DNA-DNA hybridization experiments (Hildebrand et al., 1990; Vauterin et al., 1990b). Interestingly, some of these groups contained virtually all of the pathovars from botanically related hosts. These included the pathovars from crucifers (Brassicaceae), the majority of pathovars

* Author for correspondence. Tel. (91) 645104; fax (91) 645346.

Abbreviation: FAME, fatty acid methyl ester. from leguminous hosts (Fabaceae), and a number of pathovars from cereals and grasses (family Poaceae) (Vauterin et al., 1990b).

Although the xanthomonads pathogenic for cereals and grasses constitute an important group of pathovars, little is known about their natural relationships. The exceptions in this respect are $X$. oryzae pv. oryzae and $X$. oryzae pv. oryzicola, which cause bacterial blight and streak of rice, respectively $(\mathrm{Ou}, 1972)$. These important rice pathogens have been subject to a number of taxonomic and aetiological studies (for a review see Mew, 1987). X. campestris pvs. oryzae and oryzicola were recently reclassified as $X$. oryzae pathovars (Swings et al., 1991).

$X$. campestris pv. translucens is pathogenic for a range of cereals including wheat, barley, rye and triticale. It is widespread in the USA, where it poses a problem in irrigated fields containing spring cereals (Schaad \& Forster, 1985; Shane et al., 1987). Several pathogenicity types were recognized (Boosalis, 1952; Hagborg, 1942), and these are now classified as pathovars of $X$. campestris (Dye et al., 1980), or as formae speciales of $X$. campestris pv. translucens. Strains causing bacterial blight of barley (Hordeum vulgare) are contained in $X$. campestris pv. hordei, whereas strains causing black chaff of 
wheat (Triticum aestivum) and triticale (Tritico-secale Whittmack) are classified as $X$. campestris pv. undulosa. Strains pathogenic for rye (Secale cereale) are designated $X$. campestris pv. secalis, whereas $X$. campestris pv. cerealis includes strains pathogenic for various cereals and the bromegrass Bromus inermis. In this paper these pathovars together will be named the 'translucens group'. A clear definition of these pathovars in terms of phenotype, genotype or phytopathogenic specialization is not available. The significance of the different pathovars or formae speciales within the 'translucens group' is questionable. Rather than distinct pathotypes, a variable host range depending on the individual strain has been observed (Azad \& Schaad, 1988; Cunfer \& Scolari, 1982).

$X$. campestris pv. graminis is the causal agent of bacterial wilt of various grass genera, including economically important forage and pasture grasses. The disease has been reported in Europe, the USA and New Zealand (Egli \& Schmidt, 1982; Roberts et al., 1981; Van den Mooter et al., 1987). The name $X$. graminis originally referred to all strains isolated from Festuca, Lolium, Dactylis, Phleum and Arrhenatherum (Egli et al., 1975). However, Egli \& Schmidt (1982) reported that the host range of some strains was restricted to either Phleum, Arrhenatherum or Poa. These strains were consequently renamed $X$. campestris pv. phlei, pv. arrhenatheri and pv. poae, respectively. The name $X$. campestris pv. graminis was retained for strains showing a broader host range including Lolium, Festuca, Dactylis and Trisetum. We will hereafter use the term 'graminis group' as a common name for these pathovars. Another pathovar, $X$. campestris pv. phleipratensis, causes leaf streak of Phleum pratense.

$X$. campestris pv. holcicola is the causal agent of bacterial streak disease on Sorghum bicolor and $S$. halepense (Elliott, 1930). Maize may also become infected after artificial inoculation (Leyns et al., 1984; Bradbury, 1986). Xanthomonas campestris pv. vasculorum causes gumming disease (gummosis) on sugarcane (Saccharum officinarum). Its broad host range extends to a number of other Poaceae, including maize and sorghum, and even some palms (Arecaceae). Desai et al. (1965) described $X$. campestris pv. coracanae as a pathogen causing a vascular disease of ragi (Eleusine coracana) in India.

In addition to $X$. oryzae and the $X$. campestris pathovars, two other Xanthomonas species are known to affect members of the Poaceae: $X$. albilineans causes leaf scald of sugarcane (Ashby, 1929), whereas $X$. axonopodis causes vascular gummosis disease of Axonopus scoparius and $\boldsymbol{A}$. micay grasses (Starr \& Garcés, 1950).

Little is known about the phenotypic and genomic relatedness of the $X$. campestris pathovars which are pathogenic for Poaceae. Van den Mooter et al. (1987) studied the four pathovars of grasses established by Egli \& Schmidt (1982) and concluded that each of them constituted a distinct phenotypic entity. Stead (1989) used fatty acid fingerprints to investigate the relationships between all of the pathovars from cereals and grasses. This analysis revealed two major, related groups, corresponding with the pathovars of cereals from the 'translucens group' and the pathovars of grasses from the 'graminis group'.

We report here the results of a comparative study of 146 Xanthomonas strains from cereals, grasses and other Poaceae, using SDS-PAGE of proteins, gas chromatographic analysis of fatty acid methyl esters (FAMEs), and DNA-DNA hybridization. The primary aim was to clarify the taxonomy and nomenclature of the species and pathovars of Xanthomonas which infect members of the family Poaceae.

\section{Methods}

Bacterial strains. A total of 146 strains representing all species of Xanthomonas and all $X$. campestris pathovars on members of the family Poaceae were studied. The strains used are listed in Table 1.

$S D S-P A G E$ of whole-cell proteins. Culturing of cells, preparation and electrophoresis of protein samples and densitometric recording of gels were performed as described by Vauterin et al. (1991 $a$ ). Densitometric records of gels were normalized by an iterative pattern-recognition algorithm (L. Vauterin \& P. Vauterin, unpublished), using the GelCompar 1.3 software package (Helix CV, Biotechnology Business Development, Onafhankelijkheidslaan 38, B-9000 Gent, Belgium). The generation of a database of normalized traces and comparison of traces was done using the GelCompar 1.3 software. The correlation coefficient $(r)$ was calculated between densitometric records, and cluster analysis was executed on the matrix of correlation values using the unweighted pair group method using arithmetic averages (UPGMA). The reproducibility of the electrophoresis technique was controlled (i) by preparing protein samples of all of the strains at least twice, (ii) by running most of the extracts in at least two gels, and (iii) by loading reference samples on each of the slab gels. The overall reproducibility of extraction and electrophoresis amounted to $r=0.92$.

Gas chromatographic analysis of FAMEs. Culturing of strains, extraction and quantitative analysis of FAMEs using the Hewlett Packard model 5890A gas-liquid chromatograph were done as described by Vauterin et al. (1991b). FAME fingerprints were identified and compared using the Microbial Identification System (MIS) software package (version 3.2) provided by MIDI (Microbial ID Inc., Newark, DE, USA). The Euclidean distance coefficient was calculated between profiles and clustering was achieved using UPGMA. In each of the gas chromatography runs, a calibration mixture of known standards (MIDI) and X. maltophilia strain LMG 958 were included to test the reproducibility. The variation detected among FAME profiles of different runs of strain LMG 958 was about 2 Euclidean distance units. FAME clusters were subjectively delineated at about 10 units of Euclidean distance. The mean percentages and standard deviations were calculated for each cluster. Fatty acids for which the product of the mean percentage times the percentage of samples containing the fatty acid was less than 0.25 were excluded. 
Table 1. Source and group assignment of the bacterial strains

\begin{tabular}{|c|c|c|c|}
\hline Species and/or pathovar & $\begin{array}{l}\text { Protein } \\
\text { profile }\end{array}$ & FAMEs & $\begin{array}{c}\text { DNA-DNA } \\
\text { homology }\end{array}$ \\
\hline \multicolumn{4}{|l|}{$X$. albilineans } \\
\hline LMG 482 (NCPPB 887)†, LMG 487 (NCPPB 1050), LMG 488 (NCPPB 1244) & 13 & 16 & 12 \\
\hline LMG 490 (NCPPB 2247), LMG 494' (NCPPB 2969)† & 13 & 16 & 12 \\
\hline \multicolumn{4}{|l|}{$X$. axonopodis } \\
\hline LMG 537 (ICMP 74) $\dagger$ & 10 & 18 & u \\
\hline LMG $541($ ICMP 4697)† & 10 & 18 & 9 \\
\hline LMG $542($ ICMP 4698$) \dagger$ & - & 18 & 9 \\
\hline LMG 538 (NCPPB 457)†, LMG 539 (NCPPB 2375)†, LMG 540 (NCPPB 2376) & 4 & 13 & 3 \\
\hline \multicolumn{4}{|l|}{$X$. campestris pv. arrhenatheri } \\
\hline LMG 588 (E705 T. Egli)†, LMG 590 (E711 T. Egli), LMG 591 (E720 T. Egli) & 1 & 2 & 1 \\
\hline LMG 679* (NCPPB 1944)†, LMG 880 (NCPPB 2817)†, LMG 881 (NCPPB 2819) & 1 & 3 & 1 \\
\hline LMG 887 (NCPPB 2827), LMG 890 (NCPPB 2830), LMG 7392 (NCPPB 1836) & 1 & 3 & - \\
\hline LMG 7393 (NCPPB 1943) & 1 & 3 & - \\
\hline LMG 891 (NCPPB 2831) & 1 & 4 & - \\
\hline \multicolumn{4}{|l|}{ X. campestris pv. coracanae } \\
\hline LMG 686* (NCPPB 1786)†, LMG 7476 (ICMP 2103)† & 5 & 5 & 4 \\
\hline \multicolumn{4}{|l|}{$X$. campestris pv. graminis } \\
\hline LMG 587 (IPO 118), LMG 593 (E733 T. Egli), LMG 595 (E741 T. Egli) & 2 & 1 & - \\
\hline LMG 598 (Xg81-8 F. Leyns), LMG 600 (Xg81-16 F. Leyns) & 2 & 1 & - \\
\hline LMG 607 (Xg81-28 F. Leyns), LMG 622 (Ẍg81-54 F. Leyns) & 2 & 1 & - \\
\hline LMG 623 (Xg81-56 F. Leyns), LMG 626 (Xg81-61 F. Leyns) & 2 & 1 & - \\
\hline LMG 713 (218 M. Van den Mooter)†, LMG 726* (NCPPB 2700)† & 2 & 1 & 1 \\
\hline LMG 7405 (NCPPB 2695), LMG 7406 (NCPPB 2696), LMG 7407 (NCPPB 2689) & 2 & 1 & - \\
\hline LMG 8277 (ICMP 3409) & 8 & 12 & - \\
\hline \multicolumn{4}{|l|}{$X$. campestris pv. hordei } \\
\hline LMG 737* (NCPPB 2389)†, LMG 884 (NCPPB 2824), LMG 889 (NCPPB 2829) & 1 & 4 & 1 \\
\hline LMG 8279 (ICMP 1670)†, LMG 8280 (ICMP 1671) & 1 & 4 & 1 \\
\hline LMG 879 (NCPPB 2181)†, LMG 882 (NCPPB 2820)†, LMG 8278 (ICMP 295) & 1 & 3 & 1 \\
\hline LMG 8281 (ICMP 3100) & 1 & 3 & - \\
\hline \multicolumn{4}{|l|}{$X$. campestris pv. phlei } \\
\hline LMG 716 (221 M. Van den Mooter)†, LMG 717 (222 M. Van den Mooter) & 1 & 2 & 1 \\
\hline LMG 718 (224 M. Van den Mooter), LMG 719 (227 M. Van den Mooter) & 1 & 2 & - \\
\hline LMG 720 (228 M. Van den Mooter), LMG 723 (231 M. Van den Mooter) & 1 & 1 & - \\
\hline LMG $730^{*}($ E729 T. Egli) $\dagger$ & 1 & 3 & 1 \\
\hline \multicolumn{4}{|l|}{$X$. campestris pv. phleipratensis } \\
\hline LMG 843* (NCPPB 1837)† & 1 & 1 & 1 \\
\hline \multicolumn{4}{|l|}{$X$. campestris pv. poae } \\
\hline LMG 594 (E735 T. Egli)†, LMG 728* (E724 T. Egli)† & 1 & 1 & 1 \\
\hline$X$. campestris pv. secalis & & & \\
\hline LMG 877 (NCPPB 974) & 1 & $\mathbf{u}$ & - \\
\hline LMG 883* (NCPPB 2822)†, LMG 7507 (ICMP 292)† & 1 & 3 & 1 \\
\hline$X$. campestris pv. translucens & & & \\
\hline LMG 875 (ICPB XT7), LMG 878 (NCPPB 1942), LMG 5259 (Xt102 B. Cunfer) $\dagger$ & 1 & 3 & 1 \\
\hline LMG 5260 (Xt110 B. Cunfer)†, LMG 5261 (Xt108 B. Cunfer) & 1 & 3 & 1 \\
\hline LMG 5262 (Xt110 B. Cunfer), LMG 5263 (Xt116 B. Cunfer) & 1 & 3 & - \\
\hline LMG $876^{*}($ NCPPB 973)† & 1 & 4 & 1 \\
\hline
\end{tabular}


Table 1 - continued

\begin{tabular}{|c|c|c|c|}
\hline Species and/or pathovar & $\begin{array}{c}\text { Protein } \\
\text { profile }\end{array}$ & FAMEs & $\begin{array}{c}\text { DNA-DNA } \\
\text { homology }\end{array}$ \\
\hline \multicolumn{4}{|l|}{$X$. campestris pv. undulosa } \\
\hline LMG 885 (NCPPB 2825)†, LMG 886 (NCPPB 2826), LMG 888 (NCPPB 2828)† & 1 & 3 & 1 \\
\hline LMG $892 *$ (NCPPB 2821) $\dagger$, LMG 8283 (ICMP 282) & 1 & 3 & 1 \\
\hline LMG 8282 (ICMP 297) & 1 & 4 & - \\
\hline LMG 894 (ICPB XV24), LMG 895 (NCPPB 181)†, LMG 897 (NCPPB 184) & 4 & 14 & 3 \\
\hline LMG 898 (NCPPB 185), LMG 901*(NCPPB 796)† & 4 & 14 & 3 \\
\hline LMG 899 (NCPPB 186)†, LMG 903 (NCPPB 891) $\dagger$ & 4 & 1 & 3 \\
\hline LMG $900($ NCPPB 795)†, LMG 902 (NCPPB 889)†, LMG 8284 (ICMP 326)† & 8 & 12 & 5 \\
\hline LMG $8285($ ICMP 253)† & 6 & $\mathbf{u}$ & u \\
\hline \multicolumn{4}{|l|}{$X$. fragariae } \\
\hline LMG 704 (ICMP 3304), LMG 706 (F1 Benaki)†, LMG 707 (F8 Benaki) & 11 & 7 & 10 \\
\hline LMG 634 (CIAT 1185), LMG 635 (CIAT 1186), LMG 643 (PXO61 T. W. Mew) & $3 \mathrm{a}$ & 10 & - \\
\hline LMG 645 (T7133 Wakimoto), LMG 646 (T7147 Wakimoto) & 3a & 10 & - \\
\hline LMG 647 (T7174 Wakimoto), LMG 650 (H75304 Wakimoto) & 3a & 10 & - \\
\hline LMG 795 (NCPPB 1153)†, LMG 803 (PXO71 T. W. Mew) & 3a & 10 & 2 \\
\hline LMG 804 (PXO79 T. W. Mew), LMG 806 (PXO86 T. M. Mew) & $3 a$ & 10 & - \\
\hline LMG $5047^{\top}$ (ICMP 3125)†, LMG 6518 (IRN 235 IRRI)† & $3 a$ & 10 & 2 \\
\hline \multicolumn{4}{|l|}{$X$. oryzae pv. oryzicola } \\
\hline LMG 654 (ICMP 1621), LMG 656 (ICMP 3129), LMG 657 (ICMP 3130) & $3 b$ & 11 & - \\
\hline LMG 658 (ICMP 3131), LMG 660 (ICMP 3133), LMG 661 (ICMP 3134) & $3 \mathbf{b}$ & 11 & - \\
\hline LMG 665 (ICMP 4645) $\dagger$, LMG 792 (NCPPB 1150), LMG 793 (NCPPB 11581) $\dagger$ & $3 b$ & 11 & 2 \\
\hline LMG 797* (NCPPB 15685)†, LMG 798 (NCPPB 1632) & $3 b$ & 11 & 2 \\
\hline \multicolumn{4}{|l|}{$X$. populi } \\
\hline LMG 974 (PC3 M. Ridé)†, LMG 975 (S8 M. Ridé), LMG 5743T (CNBP 1817)† & 12 & 17 & 11 \\
\hline
\end{tabular}

Abbreviations and symbols for strains: ATCC, American Type Culture Collection, Rockville, MD, USA; CFBP, Collection Française de Bactéries Phytopathogènes, Paris, France; CIAT, Rhizobium Collection, Centro Internacional de Agricultura Tropical, Cali, Colombia; CNBP, Collection Nationale de Bactéries Phytopathogènes, Angers, France; HMB, Collection of H. Maraite, Louvain-la-Neuve, Belgium; ICMP, International Collection of Micro-organisms from Plants, Auckland, New Zealand; ICPB, International Collection of Phytopathogenic Bacteria, Davis, CA, USA; IPO, Instituut voor Plantenziektenkundig Onderzoek, Wageningen, The Netherlands; IRRI, International Rice Research Institute, Los Baños, The Philippines; LMG, Laboratorium voor Microbiologie Gent Culture Collection, Universiteit Gent; NCPPB, National Collection of Plant Pathogenic Bacteria, Hapenden, UK. A superscript $\mathrm{T}$ denotes a type strain, and an asterisk $\left({ }^{*}\right)$ a pathovar reference strain. $\dagger$ denotes strains which have been tested by DNA-DNA hybridization.

$\ddagger$, Not tested.; u, unclustered or ungrouped strain.

DNA hybridization. DNA was extracted from 64 strains representative of the protein and FAME clusters. High-molecular-mass DNA was purified using the method of Marmur (1961). DNA-binding measurements $(\% D)$ were obtained using the spectrophotometric method described by De Ley et al. (1970). The renaturation rates were measured in $2 \times$ SSC $(1 \times \mathrm{SSC}$ is $0.15 \mathrm{M}-\mathrm{NaCl}$ plus $0.015 \mathrm{M}$-trisodium citrate, $\mathrm{pH} \mathrm{7.0)}$ at the average optimal renaturation temperature of $80.8^{\circ} \mathrm{C}$, which was calculated from the $\mathrm{mol} \% \mathrm{G}+\mathrm{C}$ (De Ley, 1970). Each experiment was repeated at least once. The overall experimental error of the method, which was calculated from the repeats, averaged $\pm 6 \%$. In order to reduce the size of the matrix of $\% D$ values, uniform groups were delineated above $60 \%$ and the internal mean $\% D$ value together with its standard deviation was calculated for each group. Sets of $\% D$ values between these groups were averaged in the same way.

\section{Results}

\section{$S D S-P A G E$ protein patterns}

An abridged dendrogram, with homogeneous groups represented as triangles, is shown in Fig. 1. Protein clusters were delineated above $r=0 \cdot 80$, except for cluster 13 (X. albilineans), which was delineated at $r=0.74$.

All of the strains of $X$. campestris pvs. poae, phle $i$ and arrhenatheri (i.e. the 'graminis group'), all of the strains of $X$. campestris pvs. translucens, hordei, undulosa, secalis and cerealis (i.e. the 'translucens group'), and the single 


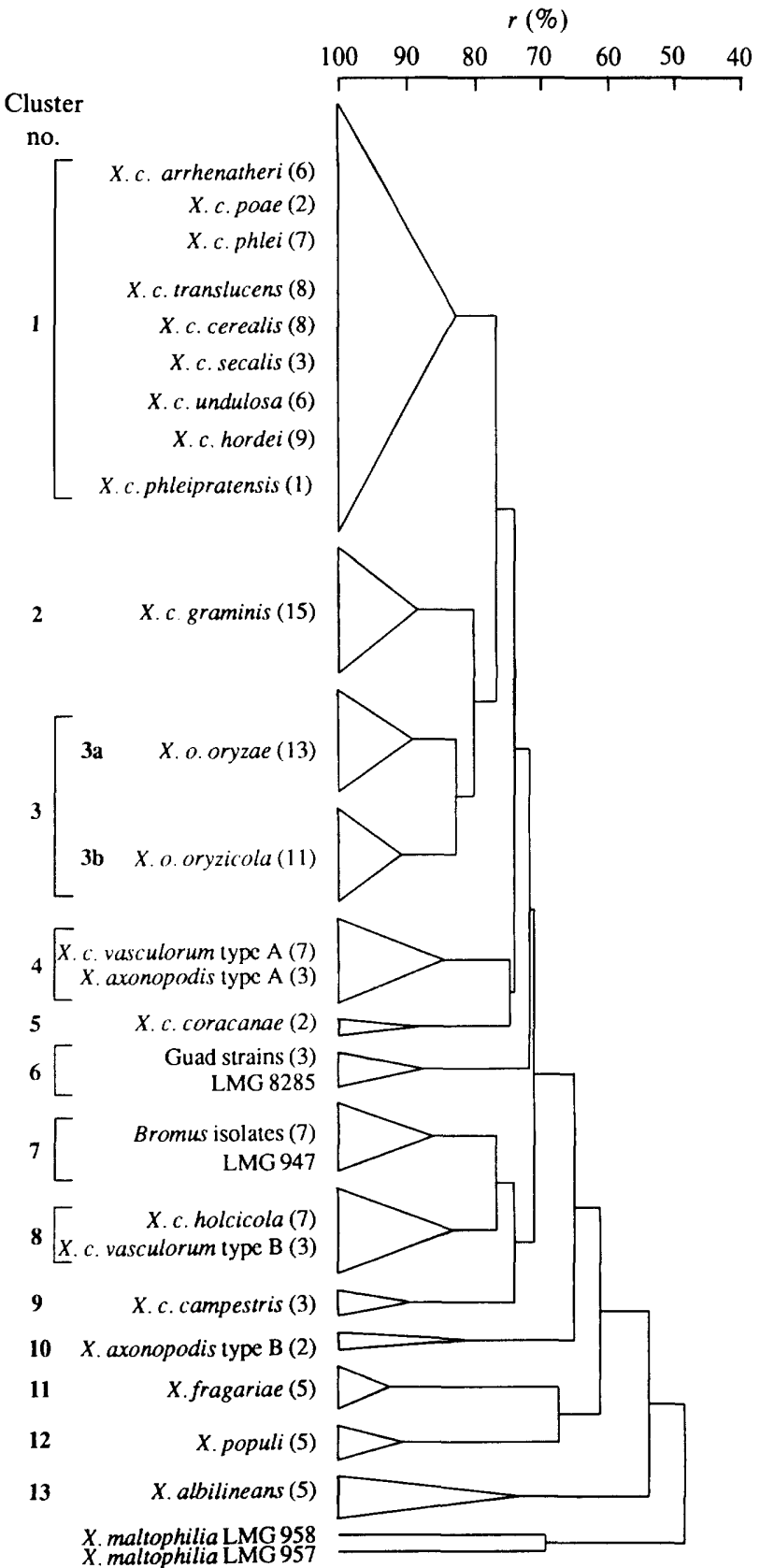

Fig. 1. Simplified dendrogram obtained by average linkage of correlation values between SDS-PAGE protein patterns of the xanthomonads studied. The number of strains per cluster is given in parentheses. X., Xanthomonas; X. c., X. campestris; X. o., X. oryzae.

strain of $X$. campestris pv. phleipratensis LMG 843 grouped together in cluster 1 . Each of the pathovars phlei, poae and arrhenatheri could be distinguished as a homogeneous subgroup within cluster 1 (data not shown). X. campestris pv. graminis (Egli \& Schmidt, 1982) constituted a distinct cluster 2 . All of the $X$. oryzae strains grouped in cluster 3 . This cluster could be subdivided into two subclusters ( $3 a$ and $3 b$ ), which corresponded to $X$. oryzae pv. oryzae and $X$. oryzae pv. oryzicola, respectively. Seven of the $X$. campestris pv. vasculorum strains, including the pathovar reference strain LMG 901 (designated $X$. campestris pv. vasculorum type A) were recovered in cluster 4 along with three $X$. axonopodis strains, including the type strain LMG 538 ( $X$. axonopodis type A). The two strains of $X$. campestris pv. coracanae constituted a separate protein electrophoretic type (cluster 5). Three strains received as $X$. albilineans from Guadeloupe (designated Guad strains) and one strain of $X$. campestris pv. vasculorum LMG 8285 from India formed a distinct cluster (cluster 6). Seven strains received as $X$. campestris pv. graminis which were isolated from Bromus wildenowii in New Zealand grouped together with $X$. campestris LMG 947 (no pathovar name), which was isolated from Bromus carinatus in France (cluster 7). A second group of $X$. campestris pv. vasculorum, comprising three strains (type B) was indistinguishable from $X$. campestris pv. holcicola (cluster 8). Three strains of $X$. campestris pv. campestris, including the type strain LMG 568, were clearly separated from all other pathovars (cluster 9). Cluster 10 comprised a second protein type of $X$. axonopodis (type B), and contained two weakly related strains, which differed strongly from the other $X$. axonopodis strains. The species $X$. fragariae, $X$. populi and $X$. albilineans were represented by clusters 11,12 and 13 , respectively. $X$. albilineans was heterogeneous on the basis of numerical analysis $(r=0.74)$. This was due to the presence of a variable heavy protein band in the $36 \mathrm{kDa}$ molecular mass zone. Two strains of $X$. maltophilia were only distantly related to the other xanthomonads $(r=0 \cdot 48)$.

\section{Fatty acid profiles}

An abridged dendrogram obtained by UPGMA analysis of the whole-cell FAME patterns for 146 strains is shown in Fig. 2. Eighteen FAME clusters were delineated at 10 Euclidean distance units while three strains remained unclustered. The fatty acid comparison within each of the groups is presented in Table 2.

The species $X$. fragariae (FAME cluster 7), $X$. albilineans (FAME cluster 16) and $X$. populi (FAME cluster 17) were homogeneous and clearly separated from each other. The fatty acid profile of $X$. maltophilia (FAME cluster 8 ) showed a high similarity to $X$. fragariae. However, $X$. maltophilia could be easily characterized by the presence of a 17:0 cyclopropane fatty acid, which was absent in all the other xanthomonads. Strains of $X$. oryzae formed two distinct and homogeneous groups, which corresponded to $X$. oryzae pv. oryzae (FAME cluster 10 ) and X. oryzae pv. oryzicola (FAME cluster 11). As observed by protein analysis, 


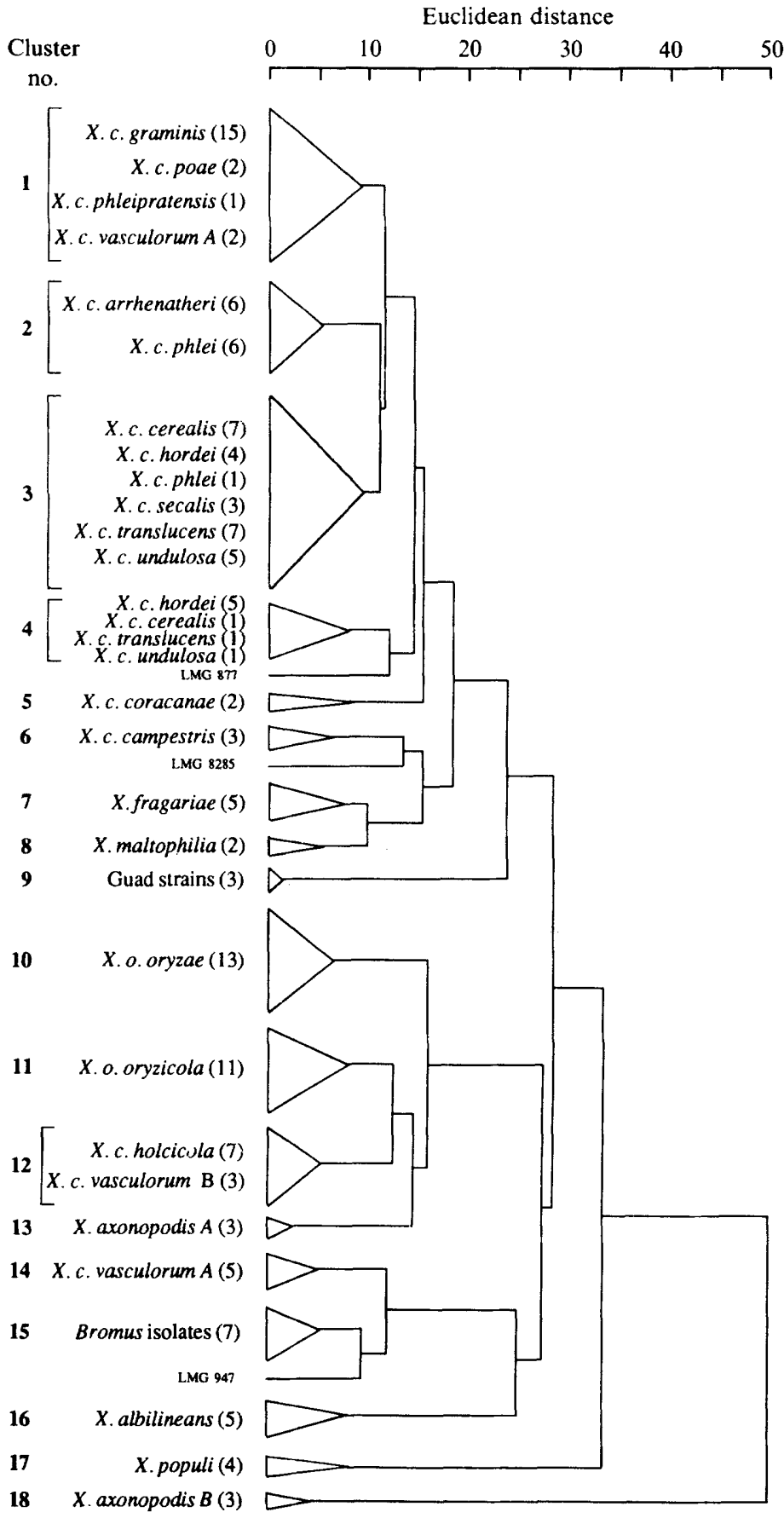

Fig. 2. Simplified dendrogram obtained by average linkage of Euclidean distance values between FAME profiles of the xanthomonads studied. The number of strains per cluster is given in parentheses. $X$., Xanthomonas; X. c., X. campestris; X. o., X. oryzae.

$X$. axonopodis consisted of two different types. FAME cluster 13 corresponded with type $\mathrm{A}$ as defined in the protein analysis, and contained the type strain. The type B strains, represented in FAME cluster 18, differed markedly from all the other xanthomonads studied, as they lacked a number of fatty acids typical of the genus Xanthomonas, for example iso-11:0, iso-3OH-11:0, iso$3 \mathrm{OH}-13: 0$, iso-15:0 and iso-17:0, whereas they produced unusually large amounts of unresolved 18:1 fatty acids termed 'summed feature 7' (see Table 2). The Guad strains received as $X$. albilineans had a highly characteristic and uniform FAME profile (FAME cluster 9).

$X$. campestris pvs. graminis and poae occurred in cluster 1 together with $X$. campestris pv. phleipratensis, whereas the other pathovars from grasses, $X$. campestris pvs. phle $i$ and arrhenatheri, were found in cluster 2. Most of the strains of the pathovars from the 'translucens group' (i.e. $X$. campestris pvs. cerealis, hordei, secalis, translucens and 
Table 2. Major fatty acids (mean percentage of total) of 18 FAME clusters of the xanthomonads used in this study

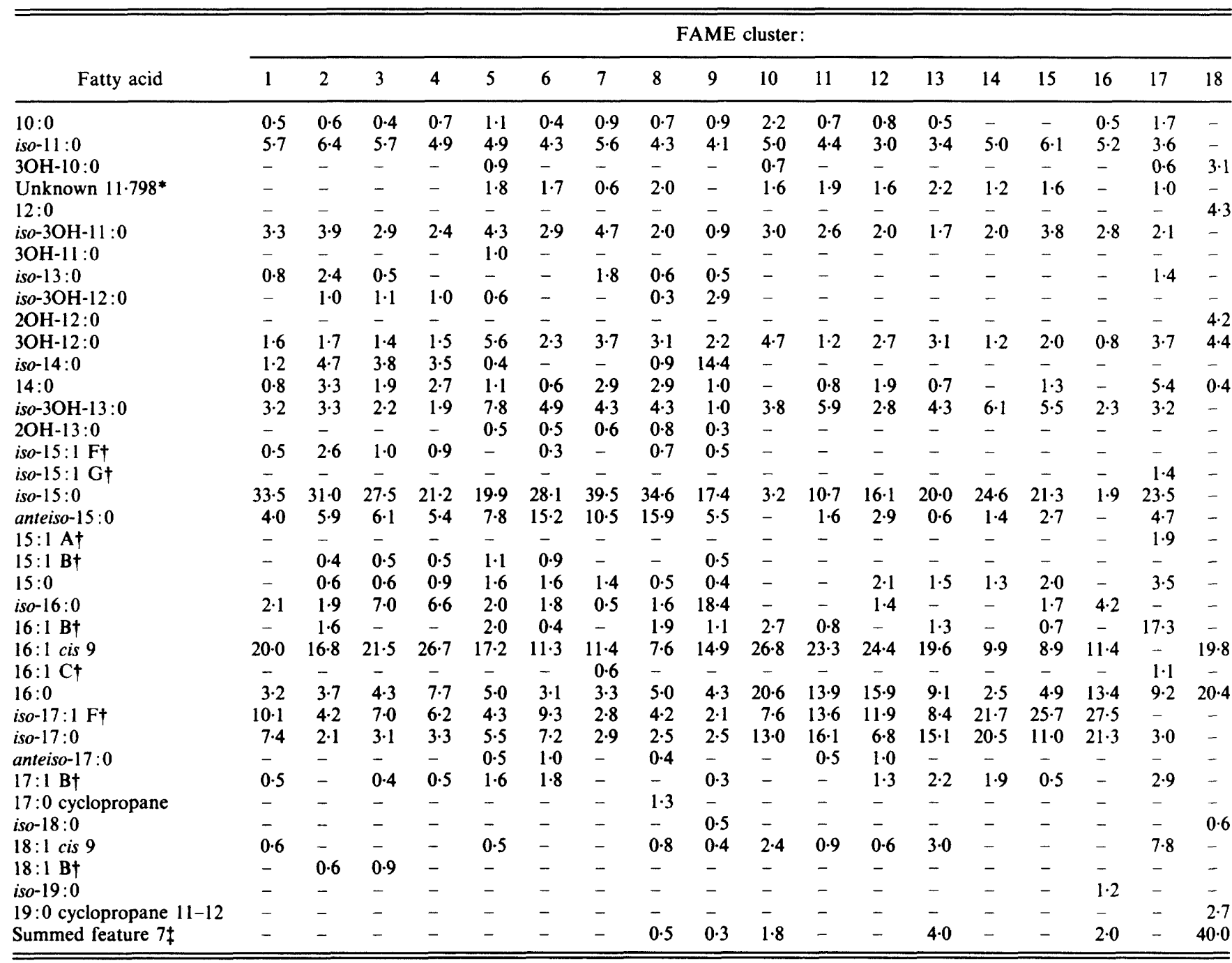

* The identity of the fatty acid which has an equivalent chain length of 11.798 is unknown.

† The double bond position indicated by the capital letters is unknown.

† Fatty acids $18: 1$ cis 11, 18:1 trans 9 and 18:1 trans 6 could not be separated from each other by gas chromatography using the MIS system and were named together summed feature 7 .

undulosa) grouped in cluster 3. Clusters 1 to 3 were closely related to each other at a level of 12 Euclidean distance units. Five strains of $X$. campestris pv. hordei and one strain each of $X$. campestris pv. cerealis, pv. translucens and pv. undulosa formed FAME cluster 4 and differed from clusters 1 to 3 mainly in that they produced a lower amount of the fatty acid iso-15:0 and a higher amount of 16:1 cis 9. The Bromus wildenowii isolates from New Zealand, received as $X$. campestris pv. graminis, were different from the other $X$. campestris pv. graminis strains and clustered in FAME cluster 15. The French Bromus carinata isolate LMG 947 was closely related to cluster 15 . Within $X$. campestris pv. vasculorum, the same types were found as revealed by protein electrophoresis.
Strains corresponding to type A were contained in FAME cluster 14, except for LMG 899 and LMG 903, which showed an overall FAME profile similar to $X$. campestris pv. graminis (cluster 1). Type B was represented in FAME cluster 12 together with $X$. campestris pv. holcicola. Xanthomonas campestris pv. coracanae had a distinct fatty acid profile (cluster 5). The strains of $X$. campestris pv. campestris were separated from all other pathovars (cluster 6).

\section{DNA hybridization}

A total of 240 DNA binding values were measured among the 64 selected strains (see Table 1). Twelve DNA 


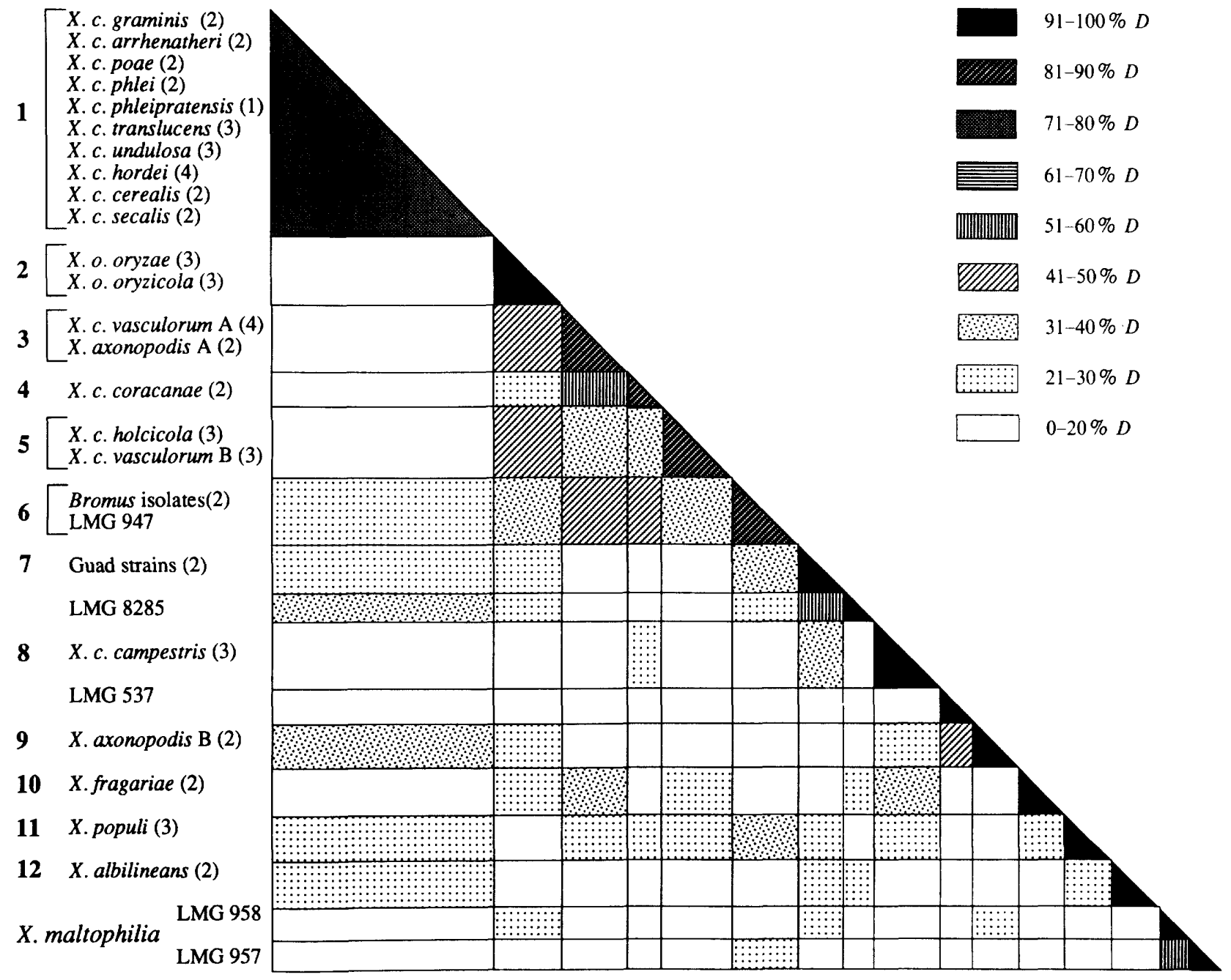

Fig. 3. Schematized DNA homology matrix showing the averaged $\% D$ values within and between DNA homology groups delineated at $60 \% D$.

homology groups were distinguished (Fig. 3). Average $\% D$ values with corresponding standard deviations for the $X$. campestris pathovars are given in Fig. 4. The groupings based on DNA homology were consistent with the clustering obtained by protein electrophoresis and FAME analysis. The species $X$. albilineans, $X$. fragariae, $X$. oryzae and $X$. populi each constituted a homogeneous DNA homology group (nos $12,10,2$ and 11 , respectively). Within $X$. oryzae, no differentiation could be made between the pathovars oryzae and oryzicola. The two $X$. maltophilia strains showed a rather low DNA homology with each other and were distinct from all the other xanthomonads. The existence of two types by protein electrophoresis within $X$. axonopodis and $X$. campestris pv. vasculorum was confirmed by DNA hybridization. $X$. axonopodis type A was related to $X$. campestris pv. vasculorum type $A$ as they were both found in DNA homology group 3. $X$. axonopodis type B strain LMG 537 was only loosely related to the other $X$. axonopodis strains of type B (DNA homology group 9). $X$. campestris pv. vasculorum type B shared high DNA binding with $X$. campestris pv. holcicola (DNA homology group 5). $X$. campestris pv. coracanae (DNA homology group 4) was related to $X$. campestris pv. vasculorum type $A$ and $X$.axonopodis type A (DNA homology group 3 ). In agreement with the results of protein electrophoresis and FAME analysis, the Bromus wildenowii isolates from New Zealand were closely related to the French isolate LMG 947 from Bromus carinatus (DNA homology group 6). The Guadeloupe strains constituted a separate group 
DNA homology group

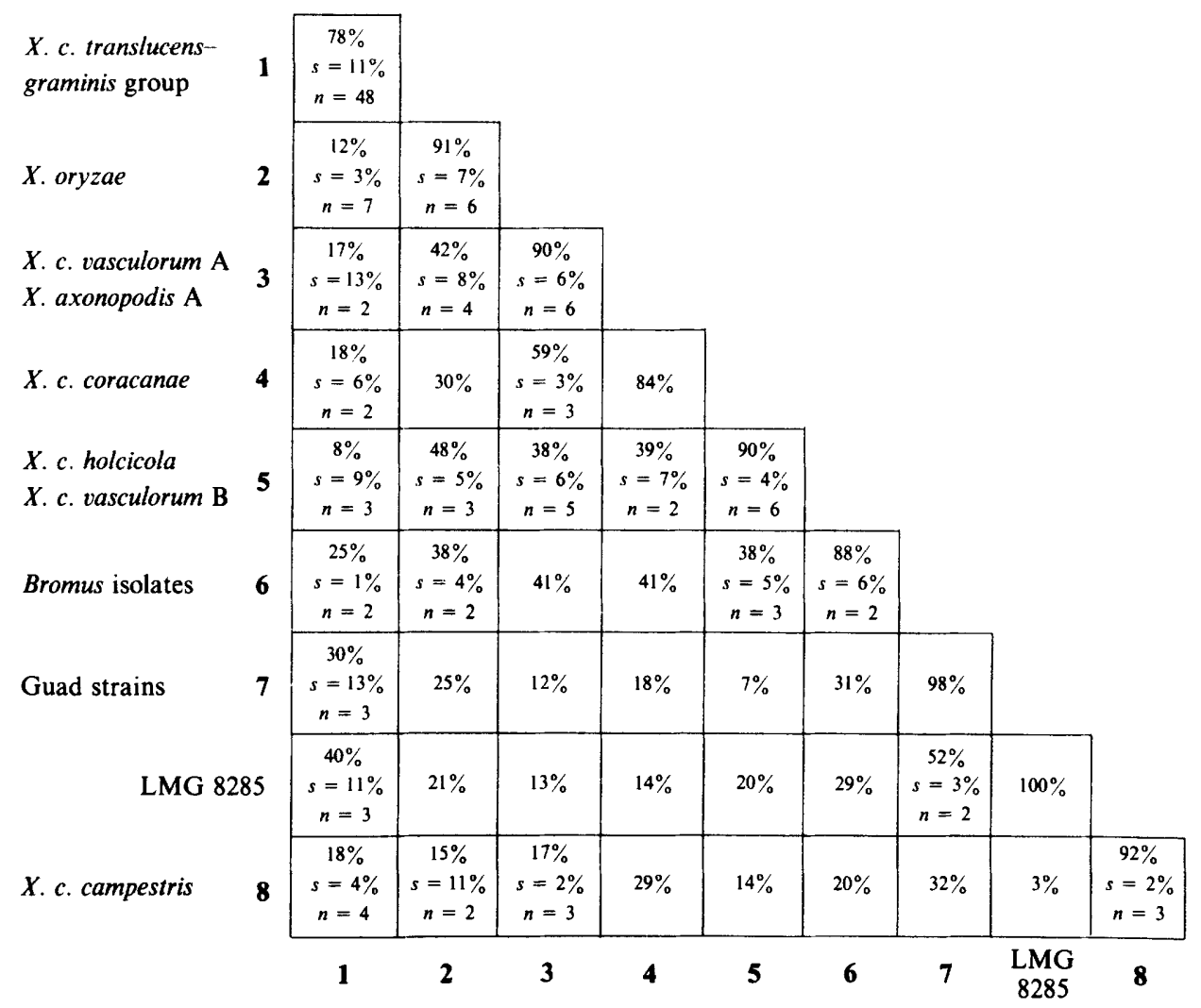

Fig. 4. Averaged $\% D$ values and corresponding standard deviations within and between DNA homology groups 1 to 8 . $s$, standard deviation; $n$, number of values.

(DNA homology group 7), with the Indian strain LMG 8285 , received as $X$. campestris pv. vasculorum, being related to it at $52 \%$.

\section{Discussion}

The pathovars of the 'translucens group' comprise a major phenotypic group of $X$. campestris pathovars from Poaceae. On the basis of the present data, no distinction can be made between the members of this group, i.e. $X$. campestris pvs. translucens, hordei, cerealis, secalis and undulosa. Furthermore, these pathovars cannot be clearly defined on the basis of pathogenicity (Cunfer \& Scolari, 1982). For example, it has been shown for $X$. campestris pv. translucens strains with a broad host range, that the pathogenicity towards certain hosts may be inactivated by single point mutations (Mellano \& Cooksey, 1988). Our results clearly support previous data on pathogenicity, serological relationships and fatty acid composition (Azad \& Schaad, 1988; Stead, 1989), which suggested that the subdivision of $X$. campestris into pvs. translucens, hordei, cerealis, secalis and undulosa (Dye et al., 1980) was not justified.

Another interesting case was represented by the pathovars of the 'graminis group'. The protein patterns for $X$. campestris pvs. arrhenatheri, phlei and poae were very similar to those for the 'translucens group'. In contrast, $X$. campestris pv. graminis had a different protein pattern. The classification of these strains as a separate pathovar of $X$. campestris (Egli \& Schmidt, 1982) seems to be justified on the basis of the present data. The FAME profiles of all of the pathovars of the 'graminis group', including $X$. campestris pv. graminis, were similar to those of the 'translucens group' (FAME clusters 1 to 3). However, it was possible to distinguish the individual pathovars graminis, arrhenatheri and phlei as each constituted a homogeneous subgroup. The single strain of $X$. campestris pv. phleipratensis was clearly distinguishable from $X$. campestris pv. phlei on the basis of protein and FAME profiles. This strain causes leaf streak on Phleum pratense, whereas strains of 
$X$. campestris pv. phlei cause bacterial wilt. DNA hybridization data revealed that all pathovars of both the 'translucens group' and the 'graminis group' were interrelated at $78 \% D$, which indicates that they all belong to the same species. The seven Bromus isolates, received as $X$. campestris pv. graminis, which were isolated in New Zealand, together with Bromus isolate LMG 947 from France were not related to $X$. campestris pv. graminis nor to any of the other species. These strains therefore constitute a new species of Xanthomonas.

Another distinct group of organisms comprised the rice pathogens $X$. oryzae pv. oryzae and $X$. oryzae pv. oryzicola. Both pathovars displayed characteristic protein and fatty acid profiles. In contrast, the DNA homology data did not reveal any difference between pathovars oryzae and oryzicola. The high genomic relatedness of the two rice pathogens $(91 \% D)$, together with their distinct position in relation to the different Xanthomonas taxa, agrees with their recent reclassification as $X$. oryzae (Swings et al., 1991). However, the different symptoms produced and the distinct phenotypes of the two groups support the retention of the pathovar names oryzae and oryzicola (Swings et al., 1991).

A more complex situation was found in $X$. axonopodis and $X$. campestris pv. vasculorum. $X$. axonopodis consisted of two substantially different groups (types A and B). Type A contained the original isolates from Colombia (Starr \& Garcés, 1950) and included the type strain LMG 538. Based on fatty acid analysis, $X$. axonopodis type B strains were not xanthomonads, as they produced a markedly different fatty acid profile from the other strains. In fact, according to the MIS library they resemble the profile of Pseudomonas aeruginosa. $X$. campestris pv. vasculorum also consisted of two types (A and B); type A strains appeared to be similar to $X$. axonopodis type A strains by protein electrophoresis and DNA hybridization, although their fatty acid profiles were different. Based on DNA hybridization, homology group 3, consisting of $X$. axonopodis type $\mathrm{A}$ and $X$. campestris pv. vasculorum type $\mathrm{A}$, was related to $X$. campestris pv. coracanae (DNA homology group 4) at $59 \% D$ (Fig. 4). A more distant relationship was also observed between these groups and DNA homology groups 2 (X. oryzae), 5 (X. campestris pvs. holcicola and vasculorum type B) and 6 (Bromus isolates). $X$. campestris pv. vasculorum type B was indistinguishable from $X$. campestris pv. holcicola by all three methods. The Indian isolate from sugarcane, LMG 8285 , received as $X$. campestris pv. vasculorum, was not related to $X$. campestris pv. vasculorum type A (DNA homology group 3) or B (DNA homology group 5). Based on DNA homology, this strain was related at $52 \%$ to the Guad strains received as $X$. albilineans from sugarcane in Guadeloupe
(DNA homology group 7). The latter strains showed no relationship to $X$. albilineans or to any of the other xanthomonads studied.

In conclusion, protein electrophoresis, fatty acid analysis, and DNA hybridization were shown to yield virtually identical groupings of the xanthomonads studied. One of the major findings of this study was that many of the Xanthomonas species and pathovars grouped into taxa which do not reflect the current classification of that genus. As discussed previously (Vauterin et al., $1990 b ; 1991 b$ ), the DNA homology groups should be the framework for a revised classification of the genus Xanthomonas. None of the DNA homology groups recovered in the present investigation showed any relationship with previously defined Xanthomonas DNA homology groups (Vauterin et al., 1990b). A future classification of the Xanthomonas taxa delineated here might be as follows.

(1) Xanthomonas oryzae, consisting of pvs. oryzae and oryzicola;

(2) Xanthomonas translucens, to include all $X$. campestris pathovars of the 'translucens group'. i.e. pvs. translucens, hordei, cerealis, undulosa and secalis (Dye et al., 1980), and the pathovars of the 'graminis group', i.e. $X$. campestris pvs. graminis, poae, phlei and arrhenatheri (Egli \& Schmidt, 1982), together with $X$. campestris pv. phleipratensis;

(3) Xanthomonas vasculorum, consisting of $X$. axonopodis $\mathrm{A}$ and $X$. campestris pv. vasculorum $\mathrm{A}$ together with $X$. campestris pv. coracanae;

(4) Xanthomonas holcicola, including $X$. campestris pv. holcicola and $X$. campestris pv. vasculorum B;

(5) Xanthomonas bromi, for the Xanthomonas isolates from Bromus;

(6) Xanthomonas sacchari, for the strains isolated from sugarcane in Guadeloupe, and possibly including the single Indian strain from sugarcane.

Some strains designated as $X$. axonopodis (i.e. type B) are misclassified as Xanthomonas.

As the DNA hybridization work within the genus Xanthomonas is still ongoing, it is possible that other $X$. campestris pathovars will be shown to share high DNA homology with one of the aforementioned groups. According to the rules of the International Code of Nomenclature of Bacteria (Lapage et al., 1975), the earliest valid specific epithet should be used for naming a species. It may thus be premature to propose formal reclassifications at this stage, as this could result in subsequent nomenclatural changes. The new species suggested here should therefore be considered as provisional entities.

L.V. and Y.P. are indebted to the Nationaal Fonds voor Wetenschappelijk Onderzoek and the Algemeen Bestuur van de 
Ontwikkelingssamenwerking, respectively. The authors acknowledge the Fonds voor Geneeskundig Wetenschappelijk Onderzoek for research grants. Part of the research was carried out in the frame of contract BAP-0138-B of the Biotechnology Action Programme of the Commission of the European Community.

\section{References}

Ashby, S. F. (1929). Gumming disease of sugar-cane. Tropical Agriculture 6, 135-138.

AZAD, H. \& SCHAAD, N. W. (1988). The relationship of Xanthomonas campestris pv. translucens to frost and the effect of frost on black chaff development in wheat. Phytopathology 78, 95-100.

Boosalis, M. G. (1952). The epidemiology of Xanthomonas translucens (J.J. and R.) Dowson on cereals and grasses. Phytopathology 42, 387-395.

Bradbury, J. F. (1986). Guide to Plant Pathogenic Bacteria. Wallingford: CAB International.

CUNFER, B. M. \& SCOLARI, B. L. (1982). Xanthomonas campestris pv. translucens on triticale and other small grains. Phytopathology 72 , 683-686.

DE LEY, J. (1970). Reexamination of the association between melting point, buoyant density, and chemical base composition of deoxyribonucleic acid. Journal of Bacteriology 101, 738-754.

De Ley, J., Cattoir, H. \& ReynaerTs, A. (1970). The quantitative measurement of DNA hybridization from renaturation rates. European Journal of Biochemistry 12, 133-142.

Desai, S. G., Thirumalachar, M. J. \& Patel, M. K. (1965). Bacterial blight disease of Eleusine coracana Gaertn. Indian Phytopathology 18, 384-386.

Dye, D. W., \& Lelliott, R. A. (1974). Genus II. Xanthomonas Dowson 1939, 187. In Bergey's Manual of Determinative Bacteriology, 8th edn, pp. 243-249. Edited by R. E. Buchanan \& N. E. Gibbons. Baltimore: Williams \& Wilkins.

Dye, D. W., Bradbury, J. F., Goto, M., Hayward, A. C., Lelliott, R. A. \& SCHROTH, M. N. (1980). International standards for naming pathovars of phytopathogenic bacteria and a list of pathovar names and pathotype strains. Review of Plant Pathology 59, 153-168.

EGLI, T. \& SCHMIDT, D. (1982). Pathogenic variation among the causal agent of bacterial wilt of forage grasses. Phytopathologische Zeitschrift 104, 138-150.

EGLI, T., Goto, M. \& SchmidT, D. (1975). Bacterial wilt, a new forage grass disease. Phytopathologische Zeitschrift 82, 111-121.

ELLIOTT, C. (1930). Bacterial streak disease of sorghums. Journal of Agricultural Research 40, 963-976.

HAGBORG, W. A. F. (1942). Classification revision in Xanthomonas translucens. Canadian Journal of Research (C) 20, 312-326.

Hildebrand, D. C., Palleroni, N. J. \& Schroth, M. N. (1990). Deoxyribonucleic acid relatedness of 24 xanthomonad strains representing 23 Xanthomonas campestris pathovars and Xanthomonas fragariae. Journal of Applied Bacteriology 68, 263-269.

Lapage, S. P., Sneath, P. H. A., Lessel, E. F., Skerman, V. B. D., SEELINGER, H. P. R. \& ClARK, W. A. (editors) (1975). International Code of Nomenclature of Bacteria, 1975 Revision. Washington, DC: American Society for Microbiology.

Leyns, F., De Cleene, M., Swings, J.-G. \& De Ley, J. (1984). The host range of the genus Xanthomonas. Botanical Review 50, 308-356.

MARMUR, J. (1961). A procedure for the isolation of deoxyribonucleic acid from microorganisms. Journal of Molecular Biology 3, 208-218.
Mellano, V. J. \& Cooxsey, D. A. (1988). Development of host range mutants of Xanthomonas campestris pv. translucens. Applied and Environmental Microbiology 54, 884-889.

MEW, T. W. (1987). Current status and future prospects of research on bacterial blight of rice. Annual Review of Phytopathology 25, 359-382.

Ou, S. H. (1972). Rice Diseases. Kew: Commonwealth Mycological Institute.

Roberts, D. L., Vargas, J. M., Detweiler, R., Baker, K. K. \& HOOPER, G. R. (1981). Association of a bacterium with a disease of tomato creeping bentgrass. Plant Disease 65, 1014-1016.

SCHAAD, N. W. \& ForsTER, R. L. (1985). A semiselective agar medium for isolating Xanthomonas campestris pv. translucens from wheat seeds. Phytopathology 75, 260-263.

Shane, W. W., Baumer, J. S. \& Teng, P. S. (1987). Crop losses caused by Xanthomonas streak on spring wheat and barley. Plant Disease 71, 927-930.

StarR, M. P. \& Garcés, O. C. (1950). El agente causante de la gomosis bacterial del pasto imperial en Colombia. Revista Facultad Nacional de Agronomia de Medellin, Colombia 12, 73-83.

STEAD, D. E. (1989). Grouping of Xanthomonas campestris pathovars of cereals and grasses by fatty acid profiling. EPPO Bulletin 19, 57-68.

Swings, J., Van den Mooter, M., Vauterin, L., Hoste, B., Gillis, M., Mew, T. W. \& Kersters, K. (1991). Reclassification of the causal agents of bacterial blight (Xanthomonas campestris pv. oryzae) and bacterial leaf streak (Xanthomonas campestris pv. oryzicola) of rice as pathovars of Xanthomonas oryzae (ex Ishiyama 1922) sp. nov., nom. rev. International Journal of Systematic Bacteriology 40 , 309-311.

Van Den Mooter, M., Steenackers, M., Maertens, C., Gosselé, F., De Vos, P., Swings, J., Kersters, K. \& De Ley, J. (1987). Differentiation between Xanthomonas campestris pv. graminis (ISPP list 1980), pv. phleipratensis (ISPP list 1980) emend., pv. paae Egli \& Schmidt 1982 and pv. arrhenatheri Egli and Schmidt 1982 by numerical analysis of phenotypic features and protein gel electrophoregrams. Journal of Phytopathology 118, 135-156.

Vauterin, L., Vantomme, R., Pot, B., Hoste, B., Swings, J. \& KERSTERS, K. (1990a). Taxonomic analysis of Xanthomonas campestris pv. begoniae and $X$. campestris pv. pelargonii by means of phytopathological, phenotypic, protein electrophoretic and DNA hybridization methods. Systematic and Applied Microbiology 13, 166-176.

Vauterin, L., Swings, J., Kersters, K., Gillis, M., Mew, T. W., Schroth, M. N., Palleroni, N. J., Hildebrand, D. C., Stead, D. E., Civerolo, E. L., Hayward, A. C., Maraite, H., Stall, R. E., Vidaver, A. K. \& Bradbury, J. F. (1990b). Towards an improved taxonomy of Xanthomonas. International Journal of Systematic Bacteriology 40, 312-316.

VAuterin, L., Swings, J. \& Kersters, K. (1991a). Grouping of Xanthomonas campestris pathovars by SDS-PAGE of proteins. Journal of General Microbiology 137, 1677-1687.

Vauterin, L., Yang, P., Hoste, B., Vancanneyt, M., Civerolo, E. L., Swings, J. \& Kersters, K. (1991b). Differentiation of Xanthomonas campestris pv. citri strains by sodium dodecyl sulphatepolyacrylamide gel electrophoresis of proteins, fatty acid analysis, and DNA-DNA hybridization. International Journal of Systematic Bacteriology 41, 535-542.

Young, J. M., Dye, D. W., Bradbury, J. F., Panagopoulos, C. G. \& RoBBs, C. F. (1978). A proposed nomenclature and classification for plant pathogenic bacteria. New Zealand Journal of Agricultural Research 21, 153-177. 